\title{
Electricity Crisis (Load Shedding) in Nepal, Its Manifestations and Ramifications
}

Ratna Sansar Shrestha

Abstract: Nepal is in the grip of electricity crisis. The electricity crisis of this millennium began in 2006. Nepal saw the last electricity crisis of the last millennium in 1999 and with the commissioning of Khimti Hydroelectric Project in 2000, there was no load shedding until 2005. Earlier, the Nepal Electricity Authority (NEA) used to attribute load shedding to "no water in rivers." Since the last wet season, however, Nepal has suffered from load shedding even while struggling with "flood" problem. With no electricity for 16 hours a day, the last dry season was the worst so far. Nepal's macro economy is suffering heavily due to this phenomenon. It is anomalous, however, that even at the time of load shedding the NEA has been spilling energy due to mismatch of system as well as transmission congestion. The NEA has promised respite from the problem in next five years, but the facts and figures do not corroborate the claim. The government of Nepal's (GoN) defective vision and short sighted policy is at the root of the problem, one that can be mitigated by setting the vision right and making the policy more forward looking and based on the principle of self-reliance.

Key words: electricity crisis, load shedding, NEA, IPPs, adverse impact, anomaly, respite, GoN Policy, tariff, Nepal

$\mathrm{T}^{\mathrm{s}}$ he 'load shedding' schedule that the Nepal Electricity Authority (NEA) publishes regularly, has become a 'must-have' document in every Nepalese household these days, such that it has gained, though cynical, popularity amongst the consumers in Nepal. It must be admitted that the NEA is both fair and equitable in making electricity available(or conversely: unavailable) as thenumber of hours consumers didn't receive electricity (or received electricity) was same for all consumers within a region. Further, the hours that the consumers didn't (or did) receive electricity was rotated such that no consumer received (or did not receive) electricity everyday during thesamewindowof time. The NEA deserves to be complimented for its competence in preparing a fair and equitable load shedding schedule and implementing it with "punctuality"!

\section{Electricity Crisis}

Nepal is being ravaged by the electricity crisis. Theelectricity crisis of this millennium began in 2006. Nepal saw the last electricity crisis of the last millennium in 1999 and, with the commissioning of Khimti Hydroelectric Project in 2000, there was no load shedding until 2005. Nepal was grappling with the problem of flood in the first week of August 2008, with resultant loss of life and limb as well as property in the hilly areas and Terai of the west Nepal. A breach of the Koshi embankment (erroneously billed as a flood) at the same time played havoc in east Nepal where people were displaced, and some were drowned, homes were washed away, and farmers' investment of time, money and energy in cultivation was washed out. Moreover, the communications network and infrastructure including road network was thrown in disarray.

Although the NEA used to trot out the excuse of no water in rivers whenever it came up with a load shedding schedule, even in such abundance (or "flood"!) it was imposing a load shedding of two hours per day, two days a week. From 27 August, 2008, the load shedding hours were increased to 16.5 hours per week. The increase of load shedding by more than four times was ascribed to (a) inability to import power from India due to collapse of a particular transmission tower in east Nepal caused by the breach of Koshi embankment, and consequent flooding of the area, and (b) low water level in Kulekhani reservoir. There was one more reason behind the "augmentation" of load shedding hours which can be gleaned by studying Table 1 . $^{1}$

From Table 1 it is clear that the load shedding of four hours per week and 16.5 hours per week during the rainy season in 2008 could also be ascribed to the fact that a number of hydroelectricity power plants were not operating at full capacity although there was no dearth of water in the rivers; i.e., of 617.28 MW installed capacity in the system at that time, the power plants were generating only 530 MW, although availability of water was not a problem. This implies that these plants were not properly maintained and, therefore, not generating at full capacity even during the wet season. In the dry season when a number of power plants are not able to generate to full capacity due to paucity of water, necessary scheduled maintenance should have been undertaken. It appears, however, that timely maintenance of these power plants was not undertaken.

Presenting the annual report for Fiscal Year 2007/8, the NEA's Managing Director mentioned that "in the dry months, shrinking of snow-fed rivers further worsen the situation and we were left with no option but to impose 48 hours-a-week load curtailment for every consumers" (NEA 2008). The load shedding timing during that fiscal year is shown on Table 2.

With the installed capacity of 615.96 MW in FY 2006/7, the NEA saw a growth in peak power demand by $11.31 \%$ and $10.76 \%$ growth in energy demand in FY 2007/8, which further 
Table 1. Availability of Electricity as of Aug 26, 2008 (Bhadra 10, 2065). ${ }^{3}$

\begin{tabular}{|c|c|c|c|}
\hline $\begin{array}{l}\text { Category } \\
\text { (RoR = Run of } \\
\text { River) }\end{array}$ & Source/ Plant & $\begin{array}{c}\text { Availability }{ }^{2} \\
\text { (MW) }\end{array}$ & $\begin{array}{l}\text { Installed } \\
\text { capacity }\end{array}$ \\
\hline \multirow[t]{9}{*}{ NEA RoR Projects } & Kali Gandaki A & 144 & 144 \\
\hline & Marsyangdi & 54 & 69 \\
\hline & Trishuli & 18 & 24 \\
\hline & Devighat & 14 & 14.1 \\
\hline & Sunkoshi & 9 & 10.05 \\
\hline & Modi & 14 & 14.8 \\
\hline & Puwa & 6 & 6.2 \\
\hline & Gandaki & 4 & 15 \\
\hline & Small & 8 & 12.704 \\
\hline Sub Total & & 271 & 309.854 \\
\hline \multirow[t]{7}{*}{ IPPs* RoR Projects } & Khimti & 60 & 60 \\
\hline & Bhotekoshi & 36 & 36 \\
\hline & Chilime & 20 & 20 \\
\hline & Jhimruk & 8 & 12 \\
\hline & Andhikhola & 5 & 5.1 \\
\hline & Indrawati & 7 & 7.5 \\
\hline & Small \& Isolated & 14 & 21.416 \\
\hline Sub Total & & 150 & 162.016 \\
\hline Total RoR Only & & 421 & 471.87 \\
\hline \multirow[t]{2}{*}{ Storage } & Kulekhani & 60 & 60 \\
\hline & Kulekhani II & 30 & 32 \\
\hline Sub Total & & 90 & 92 \\
\hline Total Hydro & & 511 & 563.87 \\
\hline \multirow[t]{2}{*}{ Thermal } & Hetauda & 9 & 14.41 \\
\hline & Duhabi & 10 & 39 \\
\hline Sub Total & & 19 & 53.41 \\
\hline Grand Total & & 530 & 617.28 \\
\hline
\end{tabular}

* IPP = Independent Power Producer

aggravated the problem, resulting in 46.5 hours-a-week load curtailment for every consumer in the dry season during that year. ${ }^{4}$ Against a demand growth of $73.34 \mathrm{MW}$ during that year, only $1.42 \mathrm{MW}$ got added to the system. ${ }^{5}$ Energy demand for theyear totaled 3,490.12 GWh, while available energy was only $3,180.66 \mathrm{GWh}$. Thevarious sources from which the energy was available in this period are shown on Table 3.

Thus, the load shedding is a function of the deficit of 309.46 GWh between energy available and energy demand during the year. The peak system demand of 721.73 MW was recorded on December 31, 2007 which is depicted on Figure 1.

\section{Undeclared Load Shedding}

According to the NEA's annual report for FY 2007/08, the NEA had 1,524,610 consumers connected to its grid, which works out to $31 \%$ of the estimated 2008 population of about 27 million. That means $69 \%$ of Nepal's population did not have to suffer from the vagaries of the NEA's load shedding; i.e., where load-shedding is unannounced but frequent or constant. The simple reason behind this is that these people, for lack of access to the services of the NEA, were under 24-hour year round load shedding. From another perspective, the load shedding could have had a lot
Table 2. Load Shedding During FY 2007/ 8

\begin{tabular}{|l|c|r|r|}
\hline Date & Duration & $\begin{array}{l}\text { MW Shed } \\
\text { (max.) }\end{array}$ & $\begin{array}{l}\text { Energy } \\
\text { Shed }\end{array}$ \\
\hline $5 / 5 / 2007$ to $8 / 8 / 2007$ & 2 & 90 & 180 \\
\hline $8 / 9 / 2007$ to $12 / 17 / 2007$ & 2 & 90 & 180 \\
\hline $12 / 18 / 2007$ to $1 / 5 / 2008$ & 3 & 150 & 250 \\
\hline $1 / 6 / 2008$ to $1 / 9 / 2008$ & 15 & 305 & 850 \\
\hline $1 / 10 / 2008$ to $1 / 31 / 2008$ & 36 & 368 & 1800 \\
\hline $2 / 1 / 2008$ to $2 / 28 / 2008$ & 46.3 & 380 & 2500 \\
\hline $2 / 29 / 2008$ to $4 / 28 / 2008$ & 36.3 & 380 & 1700 \\
\hline $4 / 29 / 2008$ to $5 / 26 / 2008$ & 21.3 & 380 & 1000 \\
\hline $5 / 27 / 2008$ to $6 / 6 / 2008$ & 9 & 280 & 500 \\
\hline $6 / 7 / 2008$ to $8 / 27 / 2008$ & 4 & 150 & 250 \\
\hline
\end{tabular}

(Source: Load Dispatch Center, NEA)

Table 3. Sources of Electricity in GWh

\begin{tabular}{|l|c|c|}
\hline Fiscal year & $\mathbf{2 0 0 7 / 0 8}$ & $\mathbf{2 0 0 6 / 0 7}$ \\
\hline Hydro generation & 1798.61 & 1747.42 \\
\hline Imported from India & 412.41 & 328.83 \\
\hline Purchase from IPPs in Nepal & 960.47 & 962.26 \\
\hline Thermal generation & 9.17 & 13.31 \\
\hline & 3180.66 & 3051.82 \\
\hline
\end{tabular}

(Source: Load Dispatch Center, NEA)

more serious adverse impact but for the fact that people in Nepal used only $70.9 \mathrm{kWh}$ per capita of electricity in 2006, which is very low compared to Iceland where (in the same year) people consumed 31,147.3 kWh per capita, highest in the world (NationMaster.com, J une 2007). The principal reason behind such low consumption of electricity in Nepal can be assessed from Figure 2 .

It is clear from the above chart that electricity as source of energy comprised only $2.04 \%$ of the total consumption of energy in $2007 / 8$, while $85 \%$ of energy consumed was from the traditional sources like firewood, agricultural residue and animal residue. In the same year the remaining $12.35 \%$ comprised of imported sources like coal and petroleum products for which Nepal paid hard-earned convertible foreign exchange (hard currency), resulting in a balance of trade deficit as well as balance of payment deficit.

There exists another facet of the problem manifest in Figure 2 that can be seen from the example of industrial corridors in Nepal's Morang-Sunsari, Bara-Parsa and Rupandehi Districts that are power-starved. It is estimated that each of these corridors require additional power of $200 \mathrm{MW}$, but due to lack of generation of electricity in the country industrial growth of the country is being suppressed and, for the same reason, the Nepalese economy is literally stagnating (or has not been allowed to grow to its full potential). This is a kind of undeclared load shedding, one that has severe adverse impact on industrialization and employment generation in the country, consequently affecting the nation's macro-economy. 


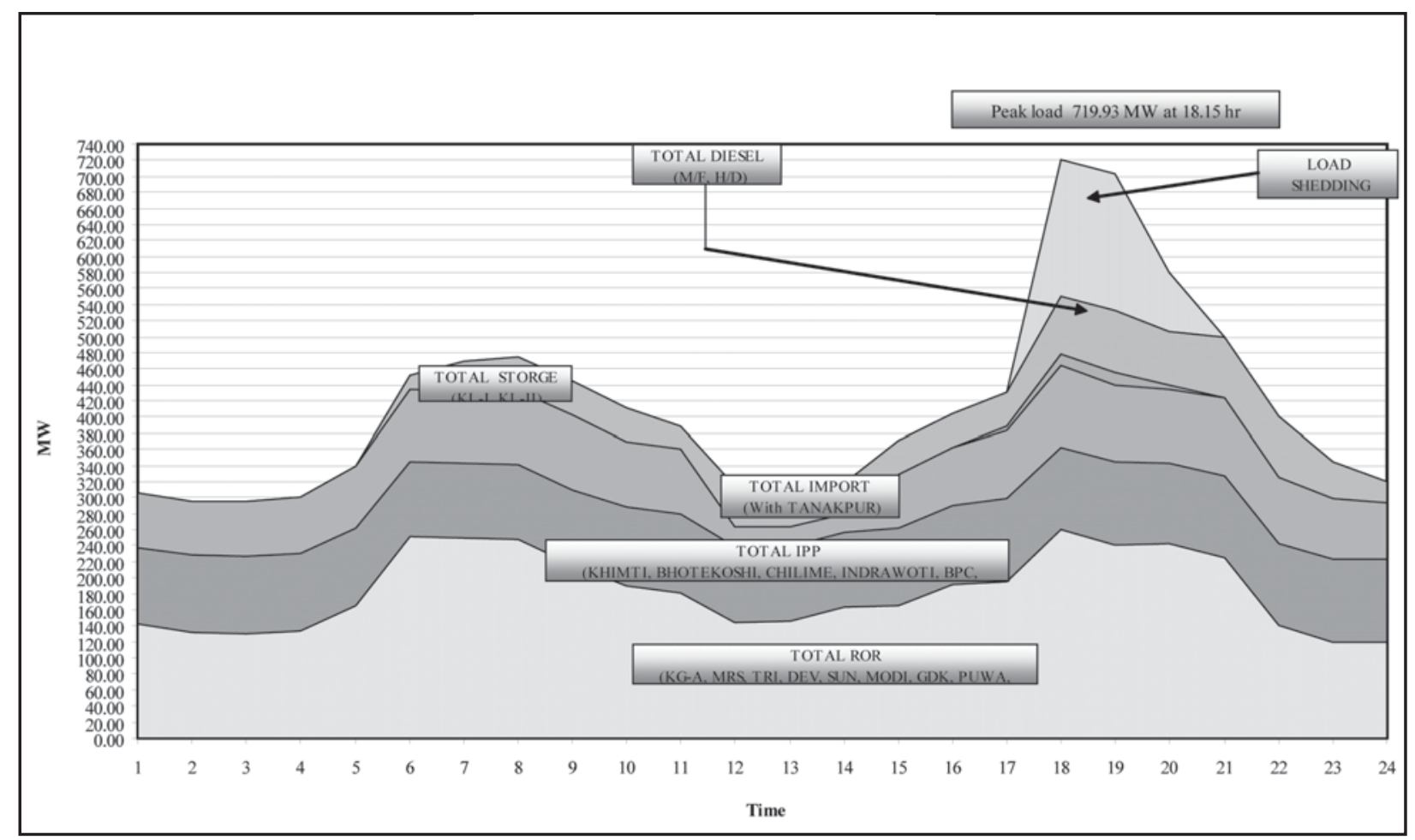

Figure 1. System Load Curve of Peak Day of the Year, December 31. 2007 (Source: NEA).

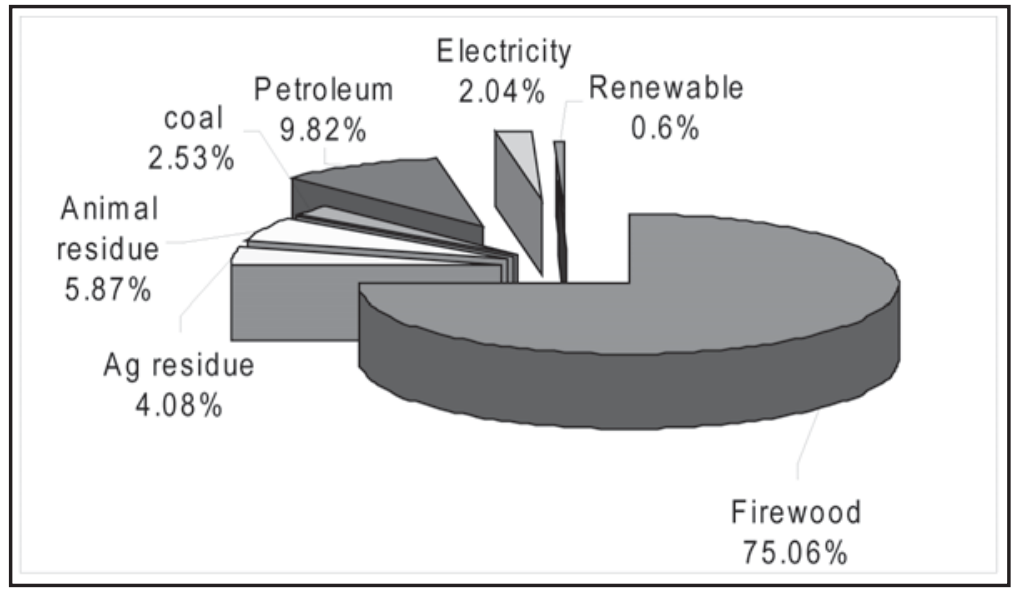

Figure 2. Energy Consumption in 2007/8: 9,858 Thousand Toe (est.) (MoF 2007). ${ }^{6}$
Forecast) one can see what the electricity demand will be up to FY 2025/26:

Having access to this information, the NEA and other policy makers must have been in a position to prepare plans for an increase in generation. It is saddening to note, however, that generation expansion has not kept pace with consumption growth. Oneof theproblems behind thisisthefailure to complete project construction and commission on time. The Middle Marsyangdi Hydro Electric project is a prime example that was originally to be completed in 2004. Looking at the magnitude of power deficit, however, it is not difficult to see that even with this project completed in a timely

Table 4. Load Shedding Forecast. ${ }^{7}$

\section{Load Shedding in Near Future}

In a presentation made by the officials of the NEA, future load shedding has been projected as shown on Table 4. This presents an unfortunate scenario for people of Nepal and its macro economy. It is also noteworthy that the actual load shedding in the dry season of 2009 was 16 hours/ day instead of projected 10 hours/ day.

\section{Why Load Shedding?}

It is rather normal for people to wonder why we have to put up with load shedding in a country that is endowed with an economic potential of 43,000 MW of hydropower. It is more surprising, knowing that relevant officials did have prior knowledge of what will be the demand for electricity in the country in specific years to come. From Table 5 (Load

\begin{tabular}{|l|l|l|l|}
\hline \multicolumn{2}{|c|}{} & Wet & Dry \\
\hline \multirow{3}{*}{$2008 / 09$} & Demand & $704 \mathrm{MW}$ & $777 \mathrm{MW}$ \\
\cline { 2 - 4 } & Supply & $668 \mathrm{MW}$ & $385 \mathrm{MW}$ \\
\cline { 2 - 4 } & Load shedding & $2 \mathrm{hrs}$ & $10 \mathrm{hrs}$ \\
\hline \multirow{3}{*}{$2009 / 10$} & Demand & $774 \mathrm{MW}$ & $845 \mathrm{MW}$ \\
\cline { 2 - 4 } & Supply & $668 \mathrm{MW}$ & $385 \mathrm{MW}$ \\
\cline { 2 - 4 } & Load shedding & $3 \mathrm{hrs}$ & $13 \mathrm{hrs}$ \\
\hline \multirow{3}{*}{$2010 / 11$} & Demand & $843 \mathrm{MW}$ & $919 \mathrm{MW}$ \\
\cline { 2 - 4 } & Supply & $668 \mathrm{MW}$ & $385 \mathrm{MW}$ \\
\cline { 2 - 4 } & Load shedding & $4 \mathrm{hrs}$ & $15 \mathrm{hrs}$ \\
\hline & Demand & $919 \mathrm{MW}$ & $1000 \mathrm{MW}$ \\
\cline { 2 - 4 } & Supply & $668 \mathrm{MW}$ & $385 \mathrm{MW}$ \\
\cline { 2 - 4 } & Load shedding & $5 \mathrm{hrs}$ & $17 \mathrm{hrs}$ \\
\hline
\end{tabular}


manner Nepal would still have faced load shedding, as other projects in the pipeline are not commensurate to growth of electricity consumption (demand).

\section{Demise of Arun III and Load Shedding}

With the country facing load shedding due to supply constraint, people ranging from the then finance minister (an economist, possessing doctorate degree) and many electricity experts (self proclaimed and otherwise) havebeen ascribing the current electricity crisis to the cancellation of Arun III in 1995, which was scheduled to be completed in 2005. This scribe, however, in an article published earlier in Hydro Nepal has proven that the ground reality is diametrically opposite to this contention (Shrestha 2009).

\section{Silver Lining}

As in all dark clouds, some silver lining may be seen in Nepal's load shedding problem. The wax candle industry, which is a flourishing cottage industry, has further flourished due to the electricity crisis. It is heart warming to note that as the candle industry has a high level of backward linkage, it must be contributing significantly to the economy. Perhaps many a marital relationships, undergoing somecrisis, must havetaken a turn for the better due to ubiquitous candle light dinners!

Similarly, sale of power inverters, batteries, generators, solar panels, etc. have also increased by a magnitude. There is nothing to be happy about the increased turnover of these, as these have to be imported. In the case of inverters, the experts opine that use of inverters at home exacerbates the problem further as these mediums store energy inefficiently. Similarly, increase in the sales of generators has contributed to aggravation the fossil fuel crisis in the country, besides contributing to environmental pollution. Due to time constraint, this paper is not able do an in-depth analysis of this aspect.

\section{Adverse Impact}

Obviously the primary impact of load shedding is on the NEA in terms of loss of revenue. In FY 2007/08 the deficit of electricity was $309.46 \mathrm{GWh}$ and at average revenue rate of Rs 6.70/kWh (see NEA 2008) the NEA could have earned Rs 2.07 billion incremental revenue and would have been able to post a net profit of Rs 761 million, instead a net loss of Rs 1.312 billion, but for this crisis.

There was a time when even hospitals suffered due to shortage of oxygen which was ascribed to unavailability of electricity. Similarly, factories operating for three shifts had to operate only two shifts and those operating two shifts had to scale down to one. It even became difficult to operate a factory for a particular shift contiguously as the load shedding occurred in the middle of a shift, which posed a new kind of challenge. Especially adversely impacted were the industries that needed to keep operating their boilers or furnaces 24 hours a day, as restarting these after a stoppage
Table 5. Load Forecast (NEA 2008).

\begin{tabular}{|l|c|c|}
\hline Year & $\begin{array}{l}\text { Energy } \\
\text { (GWh) }\end{array}$ & $\begin{array}{l}\text { Peak Load } \\
\text { (MW) }\end{array}$ \\
\hline $2008-9$ & 3620.4 & 793.3 \\
\hline $2009-10$ & 4018.4 & 878.8 \\
\hline $2010-11$ & 4430.7 & 967.1 \\
\hline $2011-12$ & 4851.3 & 1056.9 \\
\hline $2012-13$ & 5349.6 & 1163.2 \\
\hline $2013-14$ & 5859.9 & 1271.7 \\
\hline $2014-15$ & 6403.8 & 1387.2 \\
\hline $2015-16$ & 6984.1 & 1510.0 \\
\hline $2016-17$ & 7603.7 & 1640.8 \\
\hline $2017-18$ & 8218.8 & 1770.2 \\
\hline $2018-19$ & 8870.2 & 1906.9 \\
\hline $2019-20$ & 9562.9 & 2052.0 \\
\hline $2020-21$ & 10300.1 & 2206.0 \\
\hline $2021-22$ & 11053.6 & 2363.0 \\
\hline $2022-23$ & 11929.1 & 2545.4 \\
\hline $2023-24$ & 12870.2 & 2741.1 \\
\hline $2024-25$ & 13882.4 & 2951.1 \\
\hline $2025-26$ & 14971.2 & 3176.7 \\
\hline
\end{tabular}

impacted the industry grievously because reheating or restarting a boiler was a costly affair and a substantial amount of materials had to be wasted in the heating and cooling process. In order to mitigate this problem, a number of industries acquired standby generators which increased the fossil fuel crisis by a magnitude. On the other hand, even after procurement of standby generators many industries were forced to stand idly by as they were unable to operate even the standby generators due to shortage of fossil fuel to operate them.

Astudy entitled Economic Impact of Poor Power Quality on Industry: Nepal was conducted under the auspices of USAID-funded SARI/ Energy Program. The study examined the electricity supply interruptions both in terms of outages as well as loss of quality of power. Momentary interruptions, unplanned and planned outages, voltage fluctuations, and supply harmonics were considered. The conclusions relevant for the purpose of this paper are with regard to planned outages. The variation in the economic cost of planned outages in different industry categories is given in the table below. The industry-wide average cost of planned interruption is calculated to be US\$ 0.14 per $\mathrm{kWh}$ (Nexant SARI/EP 2003).

From this, it is clear that as a result of the electricity deficit of $309.46 \mathrm{GWh}$, the cost to the economy of Nepal amounted to a whopping Rs 3.25 billion due to planned interruptions (at the rate of US $14 \phi / \mathrm{kWh}$, equivalent to Rs 10.5). The study referred to here has used the cost of operating standby electricity generation to arrive at the cost of planned outage as the main component of it; but as the cost of fuel for the standby generator alone exceeds Rs 15 per $\mathrm{kWh}^{8}$ this estimate is on the lower side. Besides, this computation also ignores the cost of the chain impact on the economy in terms of lost employment, loss of purchasing 
power resulting in loss of demand for goods, consequential loss of revenue by the Government of Nepal (GoN), etc., due to unavailable power; all these culminating in reduction of GDP-the opportunity cost. Therefore, the loss to the macro economy is exponentially higher. However, it is beyond the ambit of this paper to deal with this issue.

Table 6. Economic Cost of Planned Interruptions.

\begin{tabular}{|l|c|c|}
\hline \multicolumn{1}{|c|}{ Industry } & \multicolumn{2}{c|}{ Range with 90\% confidence US\$/kWh } \\
\hline & From & To \\
\hline Food, Beverages, and Tobacco & 0.00 & 0.15 \\
\hline Chemical, Petroleum, Rubber, etc & 0.00 & 0.47 \\
\hline Textile and Leather & 0.00 & 0.74 \\
\hline Iron and Steel & 0.00 & 0.24 \\
\hline Hotels & 0.00 & 0.00 \\
\hline Non-metallic and Minerals & 0.00 & 0.57 \\
\hline Miscellaneous & 0.00 & 0.16 \\
\hline Industry Sector Average & 0.03 & 0.25 \\
\hline
\end{tabular}

Further, the load shedding problem also aggravated and compounded the fuel crisis as various factories, even shops and some households started using generators to mitigate the problem of load shedding. The use of fossil fuel as an alternative to electricity by industries and shops running backup generators, has generated environmental pollution, indoor pollution and noise pollution. ${ }^{9}$

\section{Anomaly}

There is a noteworthy anomaly in all this-spilling of electricity (wasting generation capacity) in the midst of load shedding. In FY 2007/8, as mentioned earlier, the energy demand totaled 3,490.12 GWh, while available energy was $3,180.66 \mathrm{GWh}$ only, resulting in a deficit of $309.46 \mathrm{GWh}$. However, the NEA spilled 223.378 GWh of this precious commodity during the same period (NEA 2009).

The problem can be attributed to system mismatch. Nepal's system is predominantly comprised of run-of-river power plants that generate more during the rainy season while generating close to one-third of the capacity with the discharge in the rivers going down. On the other hand, the consumption pattern in Nepal is diametrically opposite of generation by RoR (run-of-river) projects: high quantum of electricity consumption in the dry season (winter) and low consumption during wet (rainy) season.

Kulekhani I and II, totaling $92 \mathrm{MW}$, is the only storage project in Nepal, generation from which could be tailored to the demand. Therefore, the peak-in energy generated by these plants is at premium. But the source of water of this reservoir is not reliable. Such reservoirs depend on localized rain (cloudburst) to replenish the water. The water collected in this reservoir should have reached the elevation of 1,530 $m$ during the rainy season last year. The monsoon has come to a close but the water level reached only $1496 \mathrm{~m}$. In the previous year the water level reached $1516 \mathrm{~m}$; and this , too, contributed to the severity of load shedding in the last dry season. It should also be noted that the dead storage of this reservoir has already reached $25 \%$ level (i.e., the capacity of the reservoir is only $75 \%$ of what was originally built for).

Moreover, instead of using peak-in power from Kulekhani only during peak periods -in both dry and wet season-the NEA is forced to use it during other times, especially for the Birgunj-Parwanipur industrial corridor due to transmission congestion in Hetauda-Bharatpur transmission network. There were times when the NEA has spilled energy generated by Kali Gandaki A project while using electricity from Kulekhani even during normal and off-peak periods.

There is another facet of this spill story. In 2006 spring a Nepalese businessman based in India, who had lined up buyers for the spill energy as such, approached the NEA to sell such spill energy. Unfortunately for the NEA and the nation, however, the deal could not be struck. The person even demonstrated his sincerity by not asking the NEA to sell the spill energy to him without completing the due process in a transparent manner. He specifically suggested to the NEA that it do so in both competitive and transparent manner and let the bidder offering the best price strike the deal. The proposal made no progress whatsoever. It is disheartening to note that even selling such energy at Rs 1 per kWh, the NEA could easily have collected Rs 223 million which would have reduced the net loss to that extent.

\section{Promised Respite from Load Shedding}

In its annual report for FY 2007/ 8, the NEA proclaimed that "it is envisioned that Nepal would be power surplus by year 2013/14." In the capacity of a consumer suffering from the vagaries of the load shedding, one would wish luck to the NEA for the promise. The reason given was the anticipated commissioning of following projects (Table 7) by 2013/ 14 .

After implementation of the above mentioned projects, the total anticipated generation capacity in the system will be 1493.38 MW. Whether the promise will be kept, however, depends entirely on the NEA, how it functions, etc. Let's make an attempt to examine if the NEA will be able to keep the promise.

According to the load forecast of the NEA (Table 5 above) the peak demand in 2013/14 will be 1271 MW and as total available in the system will be $1493 \mathrm{MW}$; thus, superficially it would seem that there will not be any need for load shedding. Even ordinary consumers (without understanding the technicalities of electricity generation) have learned the hard way by now, however, that during the dry season (when the demand for power reaches its peak) hydropower plants do not generate to their full capacity. Therefore, in the promised year 2013/14, the peak demand will be $1271 \mathrm{MW}$ while with the total generation capacity of 
1493.38 MW the NEA will be able to generate only in the order of 7-8 hundred MW or less during the dry season.

Table 7. Projects to be Commissioned by 2013/ 14 (NEA 2008).

\begin{tabular}{|c|c|}
\hline \multicolumn{1}{|c|}{ Project Name } & Capacity in MW \\
\hline NEA Projects & \\
\hline Upper Tamakoshi & 309 \\
\hline Chamelia & 30 \\
\hline Kulekhani III & 14 \\
\hline Rahughat & 30 \\
\hline Upper Trishuli 3A & 60 \\
\hline Upper Trishuli 3B & 40 \\
\hline Upper Modi A & 42 \\
\hline Total Addition by NEA & $\mathbf{5 2 5}$ \\
\hline I PP Projects & 11 \\
\hline Sanjen Upper & 35 \\
\hline Sanjen & 80 \\
\hline Middle Bhotekoshi & 75 \\
\hline Rasuwagadhi & 30 \\
\hline Kabeli A & 50 \\
\hline Upper Marsyangdi & $\mathbf{2 8 1}$ \\
\hline Total Addition by I PPs & $\mathbf{8 0 6}$ \\
\hline $\begin{array}{l}\text { Total Addition to the System by } \\
\text { 2013/ 14 }\end{array}$ & 617.38 \\
\hline Total installed capacity till 2007/08 & 806 \\
\hline Total addition to the system by 2013/14 & 70 \\
\hline Mid-arsyangdi Commissioned 2008/09 & $\mathbf{1 4 9 3 . 3 8}$ \\
\hline $\begin{array}{l}\text { Total to be available in the system } \\
\text { in 2013/ 14 }\end{array}$ & \\
\hline
\end{tabular}

Specifically speaking, with an installed capacity of 617.38 MW in the system, 2768.25 GWh was generated in FY 2007/8, achieving a plant factor of $51.19 \%$. Therefore, if the total installed capacity is to reach 1493.38 MW in FY 2013/ 14, at the plant factor of $51.19 \%$ the generation in the dry season will be 764.40 MW only and there will be resultant shortfall of 506.60 MW; consequently a scenario for definite load shedding. Conversely, to meet the projected demand of $1271 \mathrm{MW}$ in that particular year the required installed capacity works out to $2483 \mathrm{MW}$, at the plant factor of $51.19 \%$, which is an increase by $1865 \mathrm{MW}$. Unfortunately for the consumers of electricity in Nepal, the government of Nepal is aiming to add only $876 \mathrm{MW}$ by that year ${ }^{10}$-a sure shot scenario for continued electricity crisis in and through 2013/ 14 .

It also needs to be remembered that generation capacity will reach the 1493.38 level in that year only if all the projects are commissioned in a timely manner as specified in the Table 7 above. The NEA, unfortunately, does not have a track record of completing its hydropower projects without incurring significant time overrun since the days of Kulekhani. This fact becomes clear on Table 8.

Furthermore, Table 7 also anticipates an additional 281 MW by the private sector by that time. For this purpose private investors need to able to execute power purchase agreements (PPAs) with the NEA. From the information available up to now (at the time of writing this paper), no PPA has been signed with any of the projects listed on Table 7. In view of this, the likelihood of adding $806 \mathrm{MW}$ by $2013 / 14$ is rather remote. Therefore, even if $806 \mathrm{MW}$ is added to the system there will be a short fall of $506.60 \mathrm{MW}$ and, hence, load shedding. If any of the projects listed aren't commissioned on time, the gap between demand and supply will be wider and the electricity crisis will be more severe.

Table 8. Time Overrun by Project

\begin{tabular}{|l|c|}
\hline \multicolumn{1}{|c|}{ Project Name } & Time Overrun \\
\hline Kulekhani I & 21 months \\
\hline Marsyangdi & 7 months \\
\hline Kali Gandaki A & 18 months \\
\hline Chilime & 40 months \\
\hline Middle Marsyangdi & 4 years \\
\hline
\end{tabular}

This indicates that there is something seriously wrong at various levels with comprehension of the problem, planning to mitigate the problem, and implementation of the projects. Basically, seriousness in understanding the problem is lacking and in such a scenario measures to mitigate the problem also tend to be rather sketchy.

\section{GoN Policy and Load Shedding}

Nepal's Water Resource Strategy (WECS 2002) stipulates that "by 2017, 2230 MW hydropower developed to meet projected demand of $2230 \mathrm{MW}$, including $400 \mathrm{MW}$ for export." According to load forecast prepared by the NEA (Table 5, above) peak demand in FY 2017/ 18 is estimated at 1770.2 MW and to meet this level of demand the installed capacity will have to be at least or more than 3500 MW as power plants generate at around $50 \%$ of the installed capacity. Therefore, with 2230 MW in the system, it will generate only about 1115 MW during the dry season; thus, the plan to export $400 \mathrm{MW}$ will not be possible. Actually, if the peak load is 1770.2 MW and generation reaches 2230 MW level, the continuance of load shedding will be certain. It is clear from this that the authors of the strategy lacked necessary vision in terms of consumption pattern in Nepal and intricacies of generation plans and plants.

With regard to how much power Nepal can use, one needs to think 'outside the box' and look at the issue from a different perspective. If Nepal's economic potential of 43,000 MW is to be harnessed at the plant factor of 51.19\% (current standard of Nepal's system), the electricity available will be $7140 \mathrm{kWh}$ per capita for the current population of 27 million. With the population expected to reach 42 million by 2030, the electricity available will be a meager $4590 \mathrm{kWh}$ per capita. This point is raised here to link electricity consumption with the prosperity of a 
nation and its populace due to forward linkaged benefits like industrialization, employment generation, import substitution, etc. Nepal can even escape from current petroleum product crisis significantly by electrifying the transportation system (ranging from electric trains, trolley buses, cable cars, ropeways, electric bikes, hybrid cars, etc.). Actually Nepal should aim to maximize use of power generated by harnessing its water resource domestically and also benefit by forward linkaged benefits. The nation should use electricity to lift water to irrigate, to run cold storage facilities, to set up agro-processing industries, for the overall industrialization of Nepal, and to set up energy intensive industries.

One needs to remember that most of the prosperous countries consume electricity above 10,000 kWh per capita (Iceland consumed 31,147.292 kWh per capita in 2006, the highest in the world) and for Nepalese consumers to use $10,000 \mathrm{kWh}$ per capita the installed capacity necessary will have to be in the order of $61,000 \mathrm{MW}$, which is a lot more than even the economic potential of Nepal (43,000 MW). Given this, it is disingenuous to say that Nepal has excess capacity. Therefore, the policy and strategy adopted by the government based on the assumption that Nepal has excess hydropower potential, the only use of which is exporting it to a neighboring country, is at the root of all the problems.

Presently, the policy is focused on getting free energy by allowing developers to implement projects as exportoriented. This results in cheap and better quality electricity being exported (example is West Seti, Upper Karnali, and Arun III) while condemning people in Nepal to live in the dark due to load shedding, leaving industries to starve for energy and continuing with long queues for petroleum products that pollute the environment and make people sick, increasing the absenteeism from work, and spending hard earned money on medicine and medical treatment.

\section{The Way Forward}

All problems have solutions and load shedding problem is not different. In the following discussion, an attempt is made to come up with suggestions about how to mitigate the problem. Due to time and space constraint, however, all the issues cannot be dealt with exhaustively here, although one could come up with many more suggestions.

\section{Nepal Government policy}

Nepal government should have a policy to implement as many hydropower projects as possible with domestic investment so that investment linkaged benefit will percolate into the economy. This does not mean that we should close our doors to foreign direct investment. As long as the electricity is used for the benefit of the country, who is investing does not matter.

Secondly, Nepal should allow projects to be implemented by the investor/s (domestic or foreign) that will generate electricity at the lowest cost. Nepal should purchase all such power (at lowest possible price) and electrify the nation massively (not just for lighting a few bulbs in houses), and export at a premium price the electricity that Nepal is not able to consume. Note that India has asked for seven Indian rupees to export power from a plant in Tripura to Bangladesh (BangladeshNews. com.bd 2007). What Nepal should do is, instead of dedicated export-oriented power projects, is to plan to export energy during wet seasons and off-peak hours when she needs to spill her electricity generation capacity, while during the same window of time the electricity demand in south is at its peak, thus commanding premium tariff. In this manner we could easily get out of the trap of long term PPAs and also take advantage from the complementarity of electricity market of Nepal and India.

Nepal is facing the contradiction of having to pay higher price to import from India while exporting from Nepal at substantially lower rate. What is happening is a natural phenomenon in this kind of market. From the perspective of export of power from Nepal to India there is a monopsony market11 condition and it is only natural that the importer enjoys 'market power' and is able to dictate the price. Besides, in the power market it is also a fact of life that longer PPAs fetches lower prices while the shorter ones higher prices.

To illustrate the point, the West Seti Project has a longer PPA term, and has been given lower price while (reportedly of US 5 )); but when Nepal imports power from India we do it for the short term, and pay a high price. Besides, it should be obvious to all that Nepal may, for example, not be able to use full generation of West Seti Project only for first few years, after which Nepal will be in a position to use close to half of it. In about a dozen years, Nepal will definitely be able to use all electricity generated by this project. In view of this, it is not advisable to get into longer term PPAs.

The hydropower licensing policy also needs improvement. According to data available from the Nepal's Department of Electricity Development, the status of survey licenses issued as of October 28, 2009 is as follows, in Table 9.

Table 9. Status of Survey Licenses as of October 28, 2009.

\begin{tabular}{|c|c|c|}
\hline $\begin{array}{c}\text { Capacity range } \\
\text { in MW }\end{array}$ & $\begin{array}{c}\text { Number of } \\
\text { projects }\end{array}$ & $\begin{array}{c}\text { Cumulative capacity of survey } \\
\text { licenses issued in MW }\end{array}$ \\
\hline 1 to 10 & 231 & 1009.933 \\
\hline 10 to 100 & 75 & 3535.53 \\
\hline Larger than 100 & 18 & 4949.24 \\
\hline \multicolumn{2}{|c|}{ Total in MW } & $\mathbf{9 4 9 4 . 7 0 3}$ \\
\hline
\end{tabular}

It is interesting to note that the oldest license for a project in the range of 1-10 MW was issued in September 2004. Similarly, in the 10-100 MW range, the oldest license 
was issued in J anuary 2005. Furthermore, the oldest license for projects larger than 100 MW was issued in March 2005. For some projects the survey licenses were issued in early 2000 and were "reissued" after the licenses lapsed on expiry of the five-year license period. From this it can be fairly inferred that the "developers" securing licenses either do not possess capability to mobilize financing or aren't interested to actually implement the projects.

This state of affairs has not only precluded the genuine developers/investors from implementing projects and alleviating the electricity crisis, but has also deprived the government of Nepal from revenuestream from capacity and energy royalties that would have flown in had these projects been implemented. Therefore, government policy needs to be amended to make it difficult for people without financial capability to hoard licenses; it has been seen that some licensees even don't have necessary resource to conduct the survey (feasibility study). It is recommended that survey licenses be issued only after bank guarantee covering $10 \%$ of the cost of the project is furnished to the government; then the licensees should forfeit such guarantees if the project is not implemented at the end of the survey license period.

\section{Infrastructure}

Private investors have discovered that investment in electricity generation projects is a lucrative business. They are constrained, however, by lack of infrastructure like transmission networks and access road. From a section of this paper above we have seen that the private sector indeed does have a comparative advantage in building power plants, both from the perspective of time and of cost (in successfully avoiding time and cost overruns). Therefore, the NEA should launch a campaign to build transmission networks, and if it is constrained by financial considerations, then it should 'beg, borrow or steal' (so to speak) to build the transmission network where it enjoys both comparative and competitive advantage.

Whenever people get tired of the load curtailments, the NEA attempts to pacify its beleaguered users by saying that theNepal IndiaCross BorderTransmission LineProject (400 $\mathrm{kV}$ ) will definitely bring some relief once it is completed, as the NEA will be in a position to import more power from India. The investment for Nepal's part of the project is to be financed under the leadership of the NEA and the other part under India's Infrastructure Leasing and Financial Services (IL\&FS). Transmission networks in Butwal-Gorakhpur, Duhabi-Purnea, Dhalkebar-Muzaffarpur and AnarmaniSiliguri sections are reportedly planned, which are proposed to have $400 \mathrm{kV}$ lines, initially charged at $220 \mathrm{kV}$.

What is being forgotten here is the fact that India herself is facing an electricity crisis of a higher magnitude and it will not be easy for India to come to Nepal's rescue when its own citizens are suffering. Moreover, the connection points proposed, across the border in India, like Gorakhpur, Purnea and Muzaffarpur are load centers suffering acute power deficit. Theonly exception is Silguri, which unfortunately has not been prioritized. In reality, these cross border connections are being planned to be built to evacuate power from Nepal to India from the export-oriented projects already bagged by Indian developers, or other developers in collaboration with Indian investors, and some more that will be bagged. This becomes clear by looking at the highest priority accorded to DhalkebarMuzaffarpur trans-border transmission line that will be used to evacuate power from Arun III and Tamakoshi projects in Nepal. Actually if one is to look at the concept closely, it is an excellent modality to make the NEA invest in erecting a transmission line for India to import power from Nepal. In the normal course, transmission lines are built by the importer or the developer of export-oriented power projects.

\section{Delayed completion of projects}

A part of the load shedding problem is attributable to construction delays. Experience shows that the implementation of hydropower projects by the NEA is fraught with both cost overruns and time overrun risks. Therefore, the best use of national resource is to have hydropower projects implemented by the private sector, as it seems to be able to implement projects effectively and efficiently both in terms of cost and time.

This does not mean to imply, however, that the NEA should not be involved in the construction of hydropower projects at all. What it needs to do is to learn lessons from the projects in which it was involved in implementation in the past. All along the NEA has had a spate of trouble of suffering from both cost and time overruns. In order to mitigate these problems, the NEA should review the structure and content of construction/supply contracts that it signs with contractors and suppliers and adopt construction/supply contracts that are not open-ended (i.e. the should have a fixed time and fixed price), while not affording any latitude for increase in cost or completion time (to use the popular phrase: with no scope for any "variation order").

\section{System mismatch}

With the total installed capacity of over 687 MW now, the system is generating less than half of that during the dry season when the demand is at its peak, thereby creating the electricity crisis. Nepal not only needs to have a reliable storage project, but she should also supplement peak period demand by implementing daily pondage projects.

The NEA should also seek the cooperation of the private sector to solve the system mismatch problem, by introducing bulk time-of-day tariff besides the seasonal variation in the tariff as it has now adopted for projects of up to $25 \mathrm{MW}$. In other words, it should have provision for time-of-day tariff with seasonal variation for projects of all sizes, so that building a storage (or daily pondage) project will become lucrative for the private sector, too. 
Investment friendly environment

In order to assess the role of an investment friendly environment in theimplementation of hydropower projects, it's educative to compare the target and achievements of the Ninth and Tenth Five Year Plans. In the Ninth Five Year Plan the target was set at $293 \mathrm{MW}$ and the achievement was a heart warming 91\%, as detailed in Table 10.

Table 10. Target and Achievement During Nepal's Ninth Plan. ${ }^{12}$

\begin{tabular}{|c|c|c|c|}
\hline 9th Plan (1997-2002) & Year & \multicolumn{2}{|c|}{ MW } \\
\hline Target & & & $\mathbf{2 9 3}$ \\
\hline NEA Projects & & & \\
\hline Modi & 2000 & 14.8 & \\
\hline Puwa & 2000 & 6.2 & \\
\hline Kali Gandaki A & 2002 & 144 & \\
\hline I PP Projects & & & \\
\hline Khimti & 2000 & 60 & \\
\hline Bhote Kosi & 2001 & 36 & \\
\hline Achievement & & & $\mathbf{2 6 1}$ \\
\hline
\end{tabular}

Apparently encouraged by the target achievement of the Ninth Five Year Plan, it was targeted to add 314 MW to the system in the Tenth Plan period. However, the achievement was $39.71 \mathrm{MW}$ only, as shown below:

Table 11. Target and Achievement During the Tenth Plan.

\begin{tabular}{|c|c|c|c|}
\hline $\begin{array}{c}\text { 10th Plan } \\
\text { (2002-2007) }\end{array}$ & Year & \multicolumn{2}{|c|}{ MW } \\
\hline Target & & & $\mathbf{3 1 4}$ \\
\hline NEA Projects & & & 0 \\
\hline I PP Projects & & & \\
\hline Indrawati & 2002 & 7.5 & \\
\hline Syange & 2002 & 0.183 & \\
\hline Chilime & 2003 & 20 & \\
\hline Piluwa & 2003 & 3 & \\
\hline Rairang & 2004 & 0.5 & \\
\hline Chaku & 2005 & 1.5 & \\
\hline Sunkoshi & 2006 & 2.6 & \\
\hline Baramchi & 2007 & 0.98 & \\
\hline Khudi & 2007 & 3.45 & \\
\hline Achievement & & $\mathbf{3 9 . 7 1 3}$ & $\mathbf{3 9 . 7 1}$ \\
\hline
\end{tabular}

Besides, an array of reasons behind the plan failure as such, the main constraint during the period was the lack of investment friendly environment due to Maoist insurgency. An investment-friendly environment, manifest in political stability and law and order, is sine qua non for attracting investment, especially in hydropower, which is of a capital intensive nature.

\section{Loss control}

The NEA announced that its net system loss was $25.15 \%$ in $2007 / 08$, and $26.71 \%$ in 2006/ 07 (NEA 2008). This is the total of both technical and non-technical loss. Technical loss can be significantly reduced by up to seven or eight percentage points by strengthening the transmission network, which will definitely help in reducing load shedding duration. Currently, reduction of $1 \%$ loss is tantamount to conservation of approximately $7 \mathrm{MW}$ of power (one could even say that is equal to adding $7 \mathrm{MW}$ to the system). It costs at least one billion rupees to add seven megawatts, but to strengthen transmission lines to conserve seven megawatts it will cost less than fifty million rupees.

It is true that reduction of non-technical loss will not help reduce duration of load shedding; but that curtailing non-technical loss will also result in providing electricity to the consumers who are happy to pay instead of allowing someone else to steal it.

\section{Smart retail tariff}

At present, the NEA has a specific slab structure of tariff for all kinds of domestic consumers irrespective of whether their demand for electricity is elastic (whether consuming it for luxurious uses likeoperating air conditioner, refrigerator or laundry machines) or not (i.e., just to ward off darkness). It needs to introduce time-of-day tariffs with seasonal variation to all consumers so that people will use less electricity when pressure on peak demand is high; or those who prefer to continue with their luxurious life style with no concern for price should be made to pay a higher tariff. Actually, this is the best way to curb load shedding-by allowing demand and supply to find an appropriate price.

Moreover, the NEA has a social tariff of Rs $4 / \mathrm{kWh}$ up to $20 \mathrm{kWh}$, at which rate the NEA does not recover its cost (of generation, transmission plus distribution). Under current policy the social tariff is not limited to indigent people only. In other words, the NEA is availing this tariff to all domestic consumers across the board, irrespective of whether the power is being consumed for luxurious purposes or not, or whether the consumer deserves the subsidized tariff or not. Therefore, the NEA tariff should be amended to make social tariff available to only those who deserve it: the poorest of the poor. Under a crude estimate, just with this one change the NEA will earn an incremental revenue of one billion rupees.

\section{Encourage the private sector to install more capacity}

Due to increase in the cost of construction materials like steel, cement, etc., private developers are asking for an increase in bulk tariff that the NEA offers to the private sector. But the NEA's hands are bound, as it is in no position to raise retail tariffs without which it will be forced to incur loss of higher magnitude. The way out is to keep the bulk tariff at the same level, but for the government to exempt 
power projectsfromall import duties. TheNepal government needs to understand that it does not make sense for it to earn revenue while the NEA is hemorrhaging, because the NEA is also fully owned by the government. Instead of revenue from duties, the government should vie to reap benefit by the multiplier effects that will be caused by electrification of the country. To give a simple example, it is better to lose import revenue and have the country use more electricity from which more employment will generated, leading to rise in people's incomes (they will pay income tax), then peoples consumption will rise (from which government can collect excise duty and value added tax), etc., than attempt to collect revenue which will discourage implementation of hydropower projects leading to continued load shedding and the economy stagnating for lack of energy.

What thegovernmentneedstorememberisthatsacrificing revenue to increase domestic consumption will eventually enrich the macro-economy; hence, the government will gain from the multiplier effect on the economy due to forward linkages of electricity uses. The same is not true in the case of export oriented projects, however. If such import duty facilities were to be granted to export-oriented projects, the economy not only loses the revenue stream from the tax and duties, but Nepal's economy is also deprived of the benefit of economic linkages.

\section{Conclusion}

It is rather tragicomic to have a country like Nepal, richly endowed with water resources, suffer from the problem of load shedding. Almost a case of paucity in the midst of plenty (actually not really true as only generation potential is there but the shortage is due to no generation) which is parallel to another cliché: water, water everywhere, but not a drop to drink (a little closer to truth).

The problem is not too difficult to solve if only the hydrocracy (intelligentsia, politicos and bureaucracy involved in hydropower sector) starts to think 'outside the box'. The problem is rooted in tunnel vision; because, although the NEA has promised respite from it by 2013/14, it is clear from above discussion that even if the projects in the 'pipeline' are commissioned by the promised date, load shedding will not vanish. If projects do not materialize as envisaged, the time will come when people will start talking about when will the electricity be available (like water in the taps), rather than when electricity will not be available.

Load shedding does not happen because the decision makers are unable to figure out what the demand will be for the years to come or because such data are not available to them. If the status quo is to continue, then Nepal will be condemned to have it as a standard phenomenon, because correct decisions - with regard to policy as well as with regard to when to start implementation of specific project to augment generation capacity-are not taken at appropriate time, the bureaucracy is unable to ensure that the projects under implementation are completed within expected time. The need of the hour is to have a paradigm shift.

Ratna Sansar Shrestha, FCA is a management professional specializing in financial/economic, legal and managerial aspects of water resources sector, mainly hydropower, renewableenergy technologies, environmental enterprises, and carbon trading. He is a Fellow of Institute of Chartered Accountants of Nepal, a corporate lawyer accredited by the Nepal Bar Council, a member of Water Tariff Fixation Commission and in the Board of Directors of Everest Bank Ltd. and Butwal Power Company Ltd. He was member of the Board of Director of the NEA in 20022004. He is currently a visiting faculty at the Kathmandu University, School of Engineering, Nepal.

Corresponding address: rsansar@mos.com.np

\section{References}

Bangladeshnews.com, 2007, 'Power import from India unlikely for high tariff', Bangladesh News, December 14, 2007; URL : $\quad$ www.bangladeshnews.com.bd/2007/ 12/ 14/ powerimport-from-india-unlikely-for-high-tariff/ .

MoF, 2008, Economic Survey, Kathmandu, Ministry of Finance, Government of Nepal.

NEA, 2008, 'Fiscal Year 2007/08', in Year in Review, Kathmandu: Nepal Electricity Authority.

NEA, 2009, 'System operation' in A Year in Retrospect, Kathmandu: Nepal Electricity Authority.

Nexant SARI/EP, 2003, Economic Impact of Poor Power Quality on Industry: Nepal, Kathmandu: SARI/Energy Program, U.S. Agency for International Development; URL: WWW.SARI-ENERGY.COM.

Shrestha, R.S., 2009, Arun-III Project: Nepal's electricity crisis and its role in current load shedding and potential role 10 years hence, HydroNepal: J ournal of Water, Energy and Environment v.4.

WECS, 2002, Water Resources Strategy, Kathmandu, Water and Energy Commission Secretariat, Government of Nepal.

\section{Notes}

1. Due to unavailability of relevant data for last fiscal year (2008/9), this paper is being written on the basis of data of FY $2007 / 8$.

2. Availability shown here is machine and water availability; but due to flood, debris and sediments during this rainy season, availability may be affected in real time.

3. Source: NEA Load Dispatch Center.

4. The load shedding hours increased exponentially to 16 hrs a day during the dry season of FY 2008/9.

5. In FY 2008/ 9 the demand increased by $90.47 \mathrm{MW}$ while only $71.975 \mathrm{MW}$ was added to the system. However, the deficit between demand and supply wasn't merely $19 \mathrm{MW}$ as the added capacity to the system would generate at less than 
$50 \%$ of the capacity during the peak season.

6. As government of Nepal's Economic Survey 2007/08 was not available at the time this paper was written, the figures here are based on the previous year's publication. "Toe" stands for tons of oil equivalent.

7. These projections were figures on the condition that the Middle Marsyangdi Hydroelectric Project would be completed in 2008/09-in fact, it was inaugurated by the Nepalese Prime Minister in December 2008.

8. 3 to $3.5 \mathrm{kWh}$ of electricity can be generated from 1 litre of diesel.
9. Noise pollution, especially in malls and supermarkets, is unbearably high when these generators are operated.

10. The 70 MW Middle Marsyangdi Hydroelectric Project was commissioned in December 2008.

11. A 'monopsony market' is a market situation where there is a single buyer, in contrast to a 'monopoly market' in which many buyers vie to purchase from a single seller.

12. This table and the one immediately following was compiled by the author on the basis of information from National Planning Commission and NEA. •

\section{NEWS UPDATE - NATIONAL}

\section{0 year Hydropower Planning- Report Published:}

Ministry of Energy, Government of Nepal (GoN) has published Report on 10 years Hydropower Development Planning Task Force 2065 (2008-2009) in Nepali language. It is in three volumes, Vol I:- Main Reports, Vol II:- Group wise Report, and Vol III:- Suggestions

The task force constituted renowned members from the Water Resources/ Hydropower Sectors. GoN led by Unified Communist Party of Nepal (Maoist) had announced a target of developing 10,000 MW in 10 years. The report contains detail analysis of a) Nepal's Water Resources and its use, b) Energy demand and supply and c) Hydropower Generation. This is a detail report with analysis of its water resources potential and opportunities. It also contains a proposed schedule for implementation. It is a must have document for any Water Resources/ Hydropower Enthusiast.

This 146 pages report contains useful tables, charts, work schedule etc. There are list of PPA done with NEA, list of applications for PPA, list of license holders from DOED, list of license approved, list of identified storage projects. Overall it is a good report.

\section{Jalshrot Vikash Sanstha (JVS)/ Nepal Water Partnership (NWP):}

JVSis an organization whose objective is to create enabling environment towards Water Resources Development in Nepal. JVSorganizes meetings to discuss pertinentand burningissues in Nepal. It organized one day consultative meeting on Climate Change and Impact in Nepal on 17 December, 2009. A paper was presented by Dr. Keshav Sharma, DDG, Department of Hydrology and Meteorology. Dr. Sharma presented historical background, present observations, impact on key sectors and its effects on recent droughts and floods. He highlighted its Impact on Water Resources and its Implication of Copenhagen Conference. A second paper was presented by Dr. Binayak Bhadra on Energy Security.

\section{Workshop in Renewable Nepal}

Renewable Nepal Kickoff Workshop was held in
Kathmandu University, Dhulikhel, Nepal on October 27, 2009. The 'Renewable Nepal' project aims to stimulate industrial application research in renewable energy technologies at Nepalese Universities, by financially supporting industry institution partnership researches. The project is funded by NORAD and is jointly managed by Kathmandu University, Nepal and SINTEF Energiforsking AS (SEFAS) Norway. Under the project framework, a number of selected industry institution partnership research projects will be supported financially up to $80 \%$ of the total project costs.

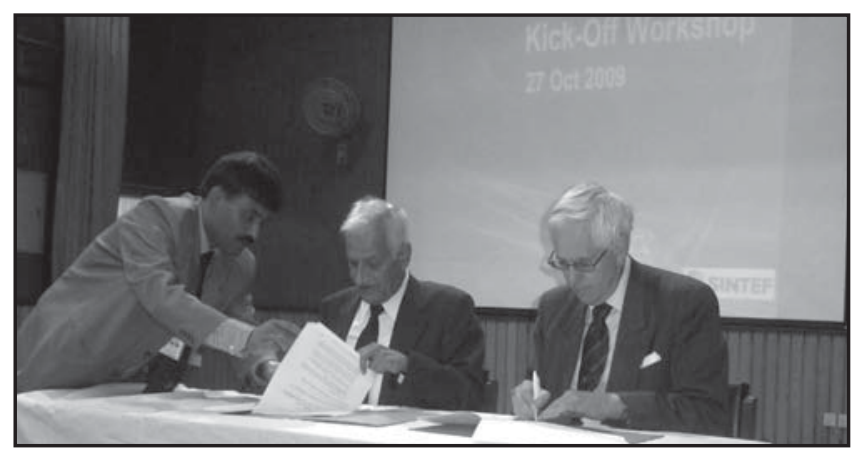

At the workshop, MOU was signed between Kathmandu University and NORAD by the Vice-Chancellor of the university Prof. Dr. Suresh Raj Sharma and His Excellency the Ambassador of Norway, Mr. Thor Gislesen respectively.

\section{Water and Energy Consultant's Association Nepal (WECAN)}

WECAN was recently formed in Kathmandu, Nepal. The association was formed with the members of hydropower and energy consultants with an aim of protecting and ensuring the benefits, interests and rights of its members and to raise common concern of quality of works. In their press release, they call for the association of all the engineers and consulting firms working in the water and energy sector with in and outside the country. WECAN is made up of 11 members committee under the presidentship of senior engineer Dr. Ramesh Maskey. • 